\title{
Queer-feministinen katse kolmen identiteettikapinallisen
}

\section{minäkuvallisuuteen}

\section{Leena-Maija Rossi}

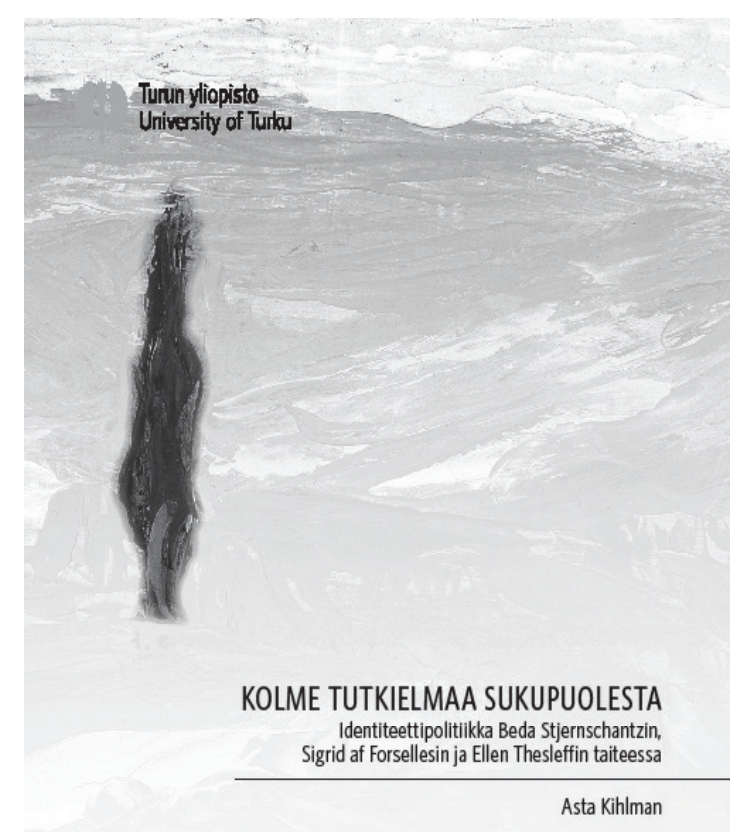

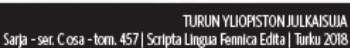

Asta Kihlman, Kolme tutkielmaa su- (1860-1935) taidetta. Kuten Kihlman tutkikupuolesta: Identiteettipolitiikka Beda Stjern- muksessaan kiehtovasti osoittaa, kaikkia schantzin, Sigrid af Forsellesin ja Ellen näitä aikalaistaiteilijoita voi perustellusti pitää Thesleffin taiteessa. Turku: Turun yliopiston eräänlaisina identiteettikapinallisina mitä tujulkaisuja Sarja C osa 457, 2018. 267 s.

Katsoessani HAMin Ellen Thesleff-näyttelyä (26.4.2019-26.1.2020) huomasin kaipaavani näyttelytekstien rakentamasta Thesleff-kuvasta selkeämpää sukupuolen ja seksuaalisuuden ambivalenssin näkökulmaa. Sellaisen tarjoaa Asta Kihlmanin väitöskirja, joka hyväksyttiin Turun yliopistossa viime vuoden lopulla. Toimin Kihlmanin vastaväittäjänä, eli minulla oli ilo saada perehtyä perusteellisesti Kolme tutkielmaa sukupuolesta -teokseen. Thesleffin (1869-1954) lisäksi väitöskirjassa käsitellään Beda Stjernschantzin (1867-1910) ja Sigrid af Forsellesin

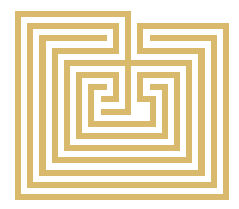
lee naissukupuoleen, sen ruumiilliseen tekemiseen ja esittämiseen.

Kihlmanin aihe on suomalaisen taidehistoriankirjoituksen kontekstissa merkittävä: vaikka kaikista kolmesta taiteilijasta on olemassa jonkin verran tutkimusta - Thesleffistä eniten - tuo Kihlmanin queer-feministinen tutkijanote arvokkaan analyyttisen lisän heidän tuotantoaan ja sen aikalaiskehystyksiä koskevaan tietoon. Queer-feministisellä otteella tarkoitetaan tässä yhteydessä tutkimuskohteen tarkastelua kriittisestä, sukupuolten ja seksuaalisuuksien normatiivisuutta purkavasta lähtökohdasta, johon liittyy erityisesti naisiksi iden- 
tifioituneiden toimijoiden toiminnan ehtojen tarkastelu.

Kihlmanin keskeisimpiä teoreettisia keskustelukumppaneita ovat Teresa de Lauretis, Sigmund Freud, Judith Butler, Judith/ Jack Halberstam, Roland Barthes, Michel Foucault, Julia Kristeva, sekä kotimaisista taidehistorioitsijoista erityisesti Harri Kalha, Tutta Palin ja Annamari Vänskä, ja allekirjoittanutkin seikkailee väitöskirjan riveillä. Kihlman kiteyttää tutkimustehtävänsä itse seuraavasti: "Sukupuoleen ja seksuaalisuuteen liittyvien analyysien avulla pyrin avaamaan vuosien 1887-1949 välillä valmistuneista taideteoksista ja muista visuaalisista aineistoista tietoa, jota ne eivät muutoin välttämättä tarjoa. Työni liittyy laajempaan symbolismitutkimuksessa käytyyn nykykeskusteluun, johon se yhdistää uutta, queer-teoreettista kuvaluentaa." (Kihlman 2018., 9-10.) Niin ikään väitöskirja tuo persoonallisen panoksen debattiin nerouden sukupuolittumisesta, jota taidehistorian piirissä on käyty useaan otteeseen niin kotimaisesti kuin kansainvälisesti.

Tutkimuksen kannalta keskeiset käsitteet, kuten queer, naismaskuliinisuus ja heteronormatiivisuus määritellään huolellisesti, niiden käyttö on enimmäkseen hyvin perusteltua ja teoreettinen kehystäminen kulkee luontevasti mukana analyysissä läpi tutkimuksen. Kihlmanin tutkimusmenetelmä on yhtäältä historiografis-diskurssianalyttinen, toisaalta hän tekee teosten yksityiskohtia tarkastellen queer-teoreettista lähiluentaa. Hän kontekstualisoi kohteensa aikalaislähteitä tarkkaan lukien ja valottaa teoksia ja tekijöitä ympäröineen taidepuheen tiukkaa kaksinapaista sukupuolittuneisuutta, mutta myös murtumia, nyrjähdyksiä ja ambivalenssia tässä puheessa. Esiin tulee niin ikään miesmaskuliinisuutta ja "kansallisen taiteen" puhtautta vaalinut taidepuheen tendenssi, yhtä lailla kuin naistaiteilijoiden tuotannon feminiinisyyden olemuksellistaminen, jota harjoittivat niin mies- kuin naiskriitikot, vaikkakin keskenään eri tavoin. Tutkija esittelee yhtenä työkalunaan minäkuvallisuuden käsitteen, jonka avulla hän lukee taiteilijoiden omakuvia ja "metonyymisiä omakuvia”. Värin merkityksellistyminen maalauksissa esimerkiksi askeesin merkitsijäksi, liaksi, ylijäämäksi, tai aistillisuuden esitykseksi saa osakseen poeettista, mutta samalla tiukan teoreettisesta pohdintaa.
Kihlmanin nykyteoriasta ponnistavat teostulkinnat ovat oivaltavia ja innovatiivisia, joskin joitakin niistä tutkija olisi vielä voinut avata hiukan pidemmälle. Kihlman itse kirjoittaa: "Luennassani omakuva laajenee identiteettipolitiikaksi, jota kutsun minäkuvallisuudeksi." (S. 16.) Identiteettipolitiikan kiistelty ja ajankohtainen käsite jää sinällään melko vähäisen käsittelyn varaan, mikä on harmi, koska sen tarkastelu olisi ollut queer-tutkimuksellisesti erittäin kiintoisaa.

Kihlman löytää keskenään hyvin erilaisia taiteilijoita yhdistäväksi tekijäksi subversiivisuuden, kumouksellisen potentiaalin, suhteessa heidän oman aikansa sukupuolta ja seksuaalisuutta normittaneisiin identiteettikategorioihin. Tämä onkin tutkimuksen keskeinen anti ja tulos. Tutkimuksessa on perehdytty taiteilijoiden tuotannoista valikoituihin teoksiin, habituksiin tai taiteilijasubjektiuteen sekä kulttuurisiin aikalaisdiskursseihin. Näitä aineistoja ja aspekteja analysoimalla tutkimus lisää tietoa siitä, kuinka sukupuoli ja seksuaalisuus merkityksellistyivät suomalaisessa taidekentässä 1800-luvun lopulla ja 1900-luvun alkupuolella - ja kuinka tätä merkityksenmuodostusta haastettiin. 
Väitöskirjan johdannossa Kihlman paikantaa itseään tutkijana ensinnäkin keskusteluun, jota hän luonnehtii postfeministiseksi viitaten käsityksiin sukupuolesta representaationa ja itserepresentaationa, rituaalina ja performatiivisesti tuottuvana tai konstruoituvana. Tässä määrittelyssään hän poikkeaa selvästi siitä keskustelusta, jossa postfeminismi mielletään feminismin jälkeiseksi tai jopa vastaiseksi ajattelu- tai toimintatavaksi. Kihlman toteaa niin ikään, että hänen omassa käytössään termi queer näyttäytyy "moninaisina minäkuvallisuuden muotoina, joilla konventionaalinen sukupuolijako ylitetään" (20). Se ei siis merkitse taiteilijoiden seksuaalisuutta määrittävää kategorisoimista, vaikka tutkimuksessa luetaankin esiin seksuaalisia tai seksuaalisuutta moninaistavia merkityksiä. Käsittelyluvuissa queer tutkimuksellisena "linssinä" nousee postfeminismiä eksplisiittisemmin esiin.

Teoksen ensimmäinen tutkielma käsittelee Beda Stjernschantzin taidetta. Kihlman keskittyy Stjernschantzin kahteen omakuvaan (1892) sekä Kaksoismuotokuva -teokseen (1895), jonka hän tulkitsee sekä muoto- että omakuvaksi. Hän lukee teosten minäkuvallisuutta epänormatiivisena, aikansa sukupuol- ta ja seksuaalisuutta rajanneita konventioita uhmanneena kumouksellisena interventiona, osallisena queeriin vastadiskurssiin. Kihlman tuo Stjernschantzin teosten rinnalle intertekstuaalisessa luennassaan myös muiden taiteilijoiden tuottamia omakuvia ja muotokuvia. Verrokkeja katseen, feminiinisten ja maskuliinisten merkkien käyttämisen, sekä naiseksi naamioitumisen kuviksi tarjoavat Helene Schjerfbeck, Magnus Enckell, Edouard Manet, Claude Cahun sekä Ellen Thesleff. Jälkimmäinen "vierailee" näin jo tutkimuksen sivuilla ennen omaa varsinaista analyysilukuaan. Kihlman tulkitsee Stjernschantzin teoksia sekä tämän aikalaissymbolisteihin vaikuttaneiden, unimaailmaan, tiedostamattomaan ja kaksoisolentoihin liittyneiden ideoiden kehyksessä että nykyfeministisen, psykoanalyysistä ammentavan Freudin uudelleentulkinnan avulla. Jälkimmäisessä analyyttisinä keskustelukumppaneina ovat etenkin lesbohalua teoretisoineet Teresa de Lauretis ja Elizabeth Grosz.

Toinen tutkielma tarkastelee Sigrid af Forsellesin reliefisarjaa Ihmissielun kehitys (1887-1903), ja keskittyy erityisesti sarjan ensimmäiseen osaan Ihmisten taistelu ( $L a$ lutte). Tutkimusaineistona on myös af Forsel- lesia ympäröinyt taidepuhe ja kampanjointi reliefien hankkimisesta kotimaiseen omistukseen. Kihlman tuo esiin, kuinka ajankohdalle poikkeuksellisesti kuvataiteilijasta kirjoittajaksi siirtynyt Helena Westermarck "neroutti" af Forsellesia - ja nosti itsensä samalla kirjailijana maskuliinisten miesnerojen rinnalle, jopa kuvataiteiljakollegojensa yläpuolelle. Mieskirjoittajat puolestaan kantoivat huolta Rodinin ateljeessakin opiskelleen af Forsellesin teosten "siveellisyydestä". Kihlmanin luennassa Ihmisten taistelu näyttäytyykin paitsi renessanssista ja barokista vaikutteita saaneena, myös syntyajankohdalleen harvinaisena naistaiteilijan teoksena, jossa mieshahmot asetettiin katsojan sukupuolesta riippumatta potentiaalisiksi polymorfisen halun kohteiksi. Tämä kumouksellinen ilmiö sitten kaapitettiin - Eve Kosofsky Sedgwickin termein - aikalaiskeskustelijoiden toimesta vaikenemisin ja koodisanoin. Taidehistorian alaston vai riisuttu (nude or naked) -keskustelu löytää tässä luvussa paikkansa, samoin rinnastus Tom of Finlandin muskelimiesten ryhmäseksikuviin sekä Edvard Munchin ja Eugéne Janssonin aikanaan hätkähdyttäneisiin alastonmaalauksiin. Af Forsellesin kuvaamat naiset Kihlman tulkitsee kiinnos- 
tavasti anti-futuurisiksi, "hedelmättömiksi" ja siksi queereiksi hahmoiksi, sekä Halberstamin näkemyksiä seuraillen, fallisiksi naismaskuliinisuuden ilmentymiksi. Kihlman löytää maskuliinisen naistaiteilijan minäkuvallisuutta myös teoksista, jotka eivät eksplisiittisesti näyttäydy omakuvallisina.

Kolmannessa tutkielmassa kohteena on Thesleffin 1890-luvun taiteilijahabitus sekä tämän 1900-luvun alkupuolen värimaalaukset ja niiden vastaanotto aina 1940-luvulle saakka. Näitä Thesleffin taiteilijuuden osa-alueita tarkastelemalla Kihlman pohtii normittavien identiteettikategorioiden pysyvyyttä sekä taiteilijuuden sukupuolittuneisuutta ja sukupuolittamisen haastamisen mahdollisuuksia. Luvun lähtökohtana ovat Thesleffistä otetut nuoruudenvalokuvat, joissa hän poseeraa maskuliinisesti, lyhythiuksisena ja vaatteissa, jotka on selvästi koodattu maskuliinisuutta tavoitteleviksi ja siten ajan sukupuolinormistoja uhmaaviksi. Kihlman nimeää foucault'laisittain poseeraukset "dandyistiseksi minätekniikaksi" ja tuo tulkintaansa mukaan myös paitsi sukupuolen, myös seksuaalisen toisintekemisen mahdollisuuden Judith Butlerin performatiivisuuden teorian pohjalta käsitteellistäen.
Kumoukselliselle poseeraamiselle otollinen konteksti löytyi toissavuosituhannen vaihteessa pariisilaisesta kulttuurieliitin ja taiteilijoiden maailmasta, Thesleffin opiskelukaupungista. Thesleffin sukupuoliambivalenssiin muotoutuu kuitenkin Kihlmanin tarkastelussa vielä useampia kerroksia, kun hän lukee maalarin 1900-luvun alkuvuosikymmenien teosten värisymboliikkaa aikansa väriteorioita (Kandinsky), kritiikkivastaanottoa, ja Julia Kristevan myöhempää väriteoretisointia sekä Mihail Bahtinin groteskin ruumiillisuuden kuvauksia vasten. Kritiikin analyysi paljastaa, kuinka mies- ja naiskriitikot tulkitsivat Thesleffin teosten värejä ja viivan laatua kovin eri tavoin, mutta kaikki kuitenkin taiteilijaa binaarisesti sukupuolittaen.

Loppuluvussa Kihlman marssittaa esiin vielä yhden uuden käsitteen: genderfuck, jonka suomeksi voi kääntää vaikkapa sukupuolihäiriköinniksi. Sillä hän tavoittelee kokoavaa vastausta tutkimuksensa esittämiin kysymyksiin: sitä kuinka tutkittujen taiteilijoiden taide ja olemisen tavat sekoittivat, tietoisesti tai tiedostamatta sukupuolen ja seksuaalisuuden esittämisen normeja ja konventioita, "kiinnittyivät kerrontarakenteen ulkopuoliseen" (244), määrittelyä pakenevaan, queeriin.
Aiheeltaan ja kysymyksenasetteluiltaan Kolme tutkielmaa sukupuolesta on uusia keskustelunäkökulmia avaava ja tuoreita tulkintoja esille tuova, sekä suhteessa kotimaiseen taidehistoriaan että laajemminkin sukupuolen ja seksuaalisuuden kysymysten tarkasteluun. Näiden monikerroksisten luentojen vieminen osaksi kansainvälistä taidehistorian ja queer-feministisen tutkimuksen keskustelua on toivottavasti seuraava askel väitöstyöstä eteenpäin.

Kihlman käy perusteellisesti läpi aikalaiskritiikkiä ja kampanjointia, ja tuo esiin taiteellisia vaikutussuhteita Italian varhaisrenessanssista aina modernistisiin tyyleihin. Vaikuttavalla tavalla hän pystyy myös käyttämään teoreettisia välineitä niin psykoanalyysin, semiotiikan, queer-teorian kuin mannermaisen feministisen teorian alueilta. Tutkimuksen vahvuuksiin kuuluu ilman muuta Kihlmanin teoreettinen lukeneisuus, sekä taidehistoriallisen tiedon sekä teosten läheltä katsomisen tuominen argumentaation tueksi. Rinnastukset sellaisten nykytaiteilijoiden kuin Claude Cahunin, Ana Mendietan ja Tom of Finlandin teoksiin osoittavat ilahduttavaa taidehistoriallista mielikuvitusta ja kekseliäisyyttä. Tulkinnat sisältävät yllättäviä ja epä- 
konventionaalisia näkökulmia. Tutkimuksen tuloksena on paneutuneita, jopa heittäytyviä kuva- ja tekstianalyysejä sekä niistä muodostuvaa tietoa siitä, kuinka Stjernschantzin, Thesleffin ja af Forsellesin taiteellinen tuotanto ja heidän toimijuutensa haastoivat aikansa yhteiskunnallis-kulttuurisia käsityksiä naisten taiteilijuudesta ja subjektiudesta.

Tutkimuksen luvut muodostavat ytimekkäitä kokonaisuuksia. Kieli on paikoittain teoreettisuutta vahvasti esiin vyöryttävää, mutta enimmäkseen hyvin luettavaa ja parhaimmillaan jopa eteenpäin soljuvaa. Kihlmanilla on aiemmasta queer- ja feministisestä tutkimuksesta inspiroitunut ote - etenkin Harri Kalhan tekstuaalinen vaikutus on ilmeinen, mutta hänen oma tutkijanäänensä erottuu myös hyvin. Erityisen kriittisessä valossa hän tarkastelee 1800-luvun lopun ja 1900-luvun alun kotimaisen taidekritiikin patronoivaa seksismiä, joskus myös matronoivaa holhousta, ja seksuaalisuuden moninaisuuden väistelyä. Niin ikään hän osoittaa selvästi kuinka hänen omat tulkintansa eroavat joistakin aiemman kotimaisen tutkimuksen esittämistä näkemyksistä.

Kihlman on kirjoittanut tutkimustaan sekä analyyttisesti lukien, tarkkaan katsoen että ruumiillisesti, teosten materiaalisuutta aistien. Aineiston radikaali kehystäminen ja tulkitseminen vie lukijan mukaansa - vaikka tämä ei kaikista näkemyksistä olisi edes samaa mieltä.

FT, dos. Leena-Maija Rossi toimii sukupuolentutkimuksen yliopistonlehtorina Lapin yliopistossa. Hän on myös visuaalisen kulttuurin tutkimuksen dosentti Turun yliopistossa sekä taidehistorian ja sukupuolentutkimuksen dosentti Helsingin yliopistossa. 